\title{
MANAJEMEN RANTAI PASOKAN (SUPPLY CHAIN MANAGEMENT)
}

\author{
Hari Sucahyowati ${ }^{1)}$ \\ ${ }^{1)}$ Staf Ketatalaksanaan Pelayaran Niaga dan Kepelabuhanan \\ Akademi Maritim Nusantara Cilacap
}

\section{A. Latar Belakang Munculnya Supply Chain Management}

Munculnya Supply Chain Management dilatar belakangi oleh dua hal pokok, yaitu:

1. Adanya praktek manajemen logistik tradisional yang bersifat adversarial pada era modern ini sudah tidak relevan lagi, karena tidak dapat menciptakan keunggulan kompetitif.

Perkembangan lingkungan industri yang dinamis pada era global seperti sekarang ini menjadi pemicu bagi banyak organisasi perusahaan untuk menggali potensi yang dimiliki, serta mengidentifikasi faktor kunci sukses untuk unggul dalam persaingan. Usaha-usaha yang dilakukan diarahkan untuk memberikan produk yang terbaik bagi konsumen. Produk yang ditawarkan perusahaan kepada konsumen dalam pengertian manajemen produksi dan operasi adalah kombinasi produk barang dan jasa.

Menyajikan produk dalam arti luas, merupakan tantangan sekaligus peluang bagi sistem produksi operasi yang harus dijalankan perusahaan. Mulai dari mengidentifikasi selera konsumen sampai dengan mengupayakan seluruh kebutuhan input dari pemasok untuk memproduksi dan mendistribusikan produk tersebut sesuai dengan selera konsumen yang dibidik. Pada dasarnya konsumen mengharapkan dapat memperoleh produk yang memiliki manfaat pada tingkat harga yang dapat diterima. Untuk mewujudkan keinginan konsumen tersebut maka setiap perusahaan berusaha secara optimal untuk menggunakan asset dan kemampuan yang dimiliki untuk memberikan value terhadap harapan konsumen.Upaya ini akan menimbulkan konsekuensi biaya yang berbeda di setiap perusahaan termasuk para pesaingnya, sehingga perusahaan harus berusaha menekan atau mereduksi seluruh biaya tanpa mengurangi kualitas produk maupun standar yang sudah ditetapkan.

Salah satu upaya untuk mereduksi biaya tersebut adalah melalui optimalisasi distribusi material dari pemasok, aliran material dalam proses produksi sampai dengan distribusi produk ke tangan konsumen. Distribusi yang optimal dalam hal ini dapat dicapai melalui penerapan konsep Supply Chain Management.

2. Perubahan lingkungan bisnis yang semakin cepat dengan persaingan yang semakin ketat.

Lingkungan bisnis selalu berubah dan perubahan tersebut semakin lama semakin cepat. Perubahan ini disebabkan beberapa faktor :

a. Tuntutan konsumen yang semakin kritis. Konsumen menjadi semakin rumit dan terlalu banyak menuntut. Mereka menuntut harga murah, mutu tinggi untuk setiap produk yang ditawarkan, penyerahan yang tepat waktu, dan sesuai dengan selera mereka.

b. Infrastruktur telekomunikasi, informasi, transportasi, dan perbankan yang semakin canggih memungkinkan berkembangnya model baru dalam aliran material/produk.

c. Daur hidup produk. Daur hidup produk sangat pendek seiring dengan perubahan-perubahan yang terjadi dalam lingkungan pasar. 
d. Kesadaran konsumen akan pentingnya aspek sosial dan lingkungan dalam kehidupan, menuntut industri manufaktur memasukkan konsep-konsep ramah lingkungan mulai dari proses perancangan produk, proses produksi maupun proses distribusinya.

e. Globalisasi dan perubahan peta ekonomi dunia telah menciptakan banyak paradigma baru dalam dunia bisnis, dan salah satu paradigma penting adalah meningkatnya persaingan antara produk jasa di pasaran.

\section{B. Supply Chain dan Supply Chain Management}

Supply Chain adalah jaringan perusahaan-perusahaan yang secara bersama-sama bekerja untuk menciptakan dan menghantarkan suatu produk ke tangan pemakai akhir.

Perusahaan-perusahaan tersebut termasuk supplier, pabrik, distributor, toko atau ritel, serta perusahaan pendukung seperti jasa logistik.

Ada 3 macam hal yang harus dikelola dalam supply chain yaitu:

1. Aliran barang dari hulu ke hilir contohnya bahan baku yang dikirim dari supplier ke pabrik, setelah produksi selesai dikirim ke distributor, pengecer, kemudian ke pemakai akhir.

2. Aliran uang dan sejenisnya yang mengalir dari hilir ke hulu .

3. Aliran informasi yang bisa terjadi dari hulu ke hilir atau sebaliknya.

Sebuah rantai pasokan adalah kelompok komponen (pemasok, titik distribusi, transportasi provider) yang diperlukan untuk membawa produk dari bahan baku untuk pengguna akhir.

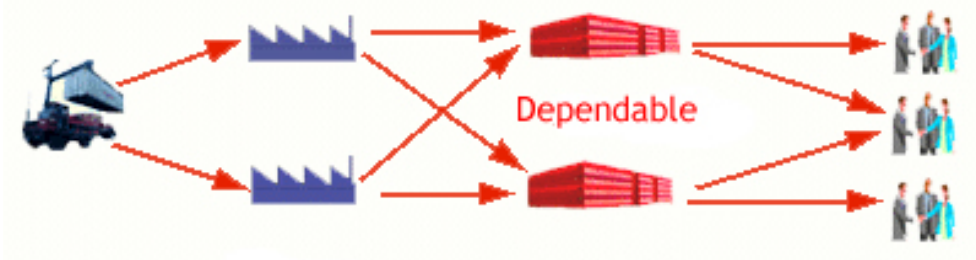

\section{Supplier Manufacturer Warehouse / D.C. Customer}

Gambar 1. Diagram supply chain

Supply chain management adalah istilah yang digunakan untuk
mengendalikan

Sebuah model rantai pasokan sederhana terdiri dari empat komponen:

1. Supplier: persediaan bahan baku

2. Produsen: menghasilkan produk

3. Gudang atau Pusat Distribusi: toko-toko dan kapal-kapal produk

4. Pengguna Akhir: menerima produk 


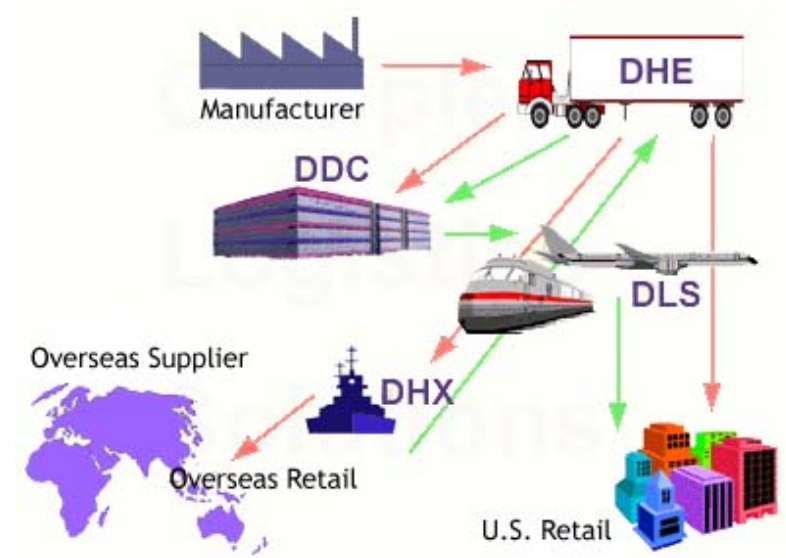

Gambar 2. Model rantai pasokan

Kalau supply chain adalah jaringan fisiknya, yakni perusahaanperusahaan yang terlibat dalam memasok bahan baku, memproduksi barang maupun mengirimkannya ke pemakai akhir, Supply Chain Management adalah metode, alat atau pendekatan pengelolaannya.

Pendekatan yang ditekankan dalam Supply Chain Management adalah terintegrasi dengan semangat kolaborasi. Supply Chain Management menekankan pada pola terpadu menyangkut proses aliran produk dari supplier, manufaktur, retailer hingga pada konsumen akhir. Dalam konsep Supply Chain Management ingin diperlihatkan bahwa rangkaian aktivitas antara supplier hingga konsumen akhir adalah dalam satu kesatuan.

Ada pula yang mengatakan bahwa Supply Chain Management adalah suatu metode penciptaan produk untuk disampaikan pada pengguna terakhir, di mana didalamnya tercakup berbagai komponen, yaitu the supplier of raw materials, the manufacturing units, warehauses, transporters, retailers, and finally selling.

Supply Chain Management tidak hanya berorientasi pada urusan internal melainkan juga eksternal perusahaan yang menyangkut hubungan dengan perusahaan-perusahaan partner.

Definisi oleh the Council of Logistics Management :

Supply Chain Mangement is the systematic, strategic coordination of the traditional business functions within a particular company and across businesses within the supply chain for the purpose of improving the long-term performance of the individual company and the supply chain as a whole.

Perusahaan yang berada dalam supply chain pada intinya memuaskan konsumen dengan bekerja sama membuat produk yang murah, mengirimkan tepat waktu dan dengan kualitas yang bagus.

Persaingan yang terjadi sekarang bukanlah perusahaan satu dengan yang lainnya, tapi lebih tepat dikatakan supply chain yang satu dengan supply chain yang lain.

Semangat kolaborasi dan koordinasi antar perusahaan dalam supply chain harus diutamakan, tapi tidak mengorbankan kepentingan tiap individu perusahaan. 
Idealnya hubungan perusahaan antar supply chain adalah jangka panjang, sehingga tercipta kepercayaan dan efisiensi.

\section{Manfaat Supply Chain Management}

Secara umum penerapan konsep Supply Chain Management dalam perusahaan akan memberikan manfaat yaitu (Jebarus, 2001) kepuasan pelanggan, meningkatkan pendapatan, menurunnya biaya, pemanfaatan asset yang semakin tinggi, peningkatan laba, dan perusahaan semakin besar.

1. Kepuasan pelanggan. Konsumen atau pengguna produk merupakan target utama dari aktivitas proses produksi setiap produk yang dihasilkan perusahaan. Konsumen atau pengguna yang dimaksud dalam konteks ini tentunya konsumen yang setia dalam jangka waktu yang panjang. Untuk menjadikan konsumen setia, maka terlebih dahulu konsumen harus puas dengan pelayanan yang disampaikan oleh perusahaan.

2. Meningkatkan pendapatan. Semakin banyak konsumen yang setia dan menjadi mitra perusahaan berarti akan turut pula meningkatkan pendapatan perusahaan, sehingga produk-produk yang dihasilkan perusahaan tidak akan 'terbuang' percuma, karena diminati konsumen.

3. Menurunnya biaya. Pengintegrasian aliran produk dari perusahan kepada konsumen akhir berarti pula mengurangi biaya-biaya pada jalur distribusi.

4. Pemanfaatan asset semakin tinggi. Aset terutama faktor manusia akan semakin terlatih dan terampil baik dari segi pengetahuan maupun keterampilan. Tenaga manusia akan mampu memberdayakan penggunaan teknologi tinggi sebagaimana yang dituntut dalam pelaksanaan Supply Chain Management.

5. Peningkatan laba. Dengan semakin meningkatnya jumlah konsumen yang setia dan menjadi pengguna produk, pada gilirannya akan meningkatkan laba perusahaan.

6. Perusahaan semakin besar. Perusahaan yang mendapat keuntungan dari segi proses distribusi produknya lambat laun akan menjadi besar, dan tumbuh lebih kuat.

Keenam manfaat yang sudah dijelaskan seperti tersebut di atas merupakan manfaat tidak langsung. Secara umum, manfaat langsung dari penerapan Supply Chain Management bagi perusahaan adalah :

1. Supply Chain Management secara fisik dapat mengkonversi bahan baku menjadi produk jadi dan mengantarkannya kepada konsumen akhir. Manfaat ini menekankan pada fungsi produksi dan operasi dalam sebuah perusahaan. Dalam fungsi ini dilakukan penggunaan dari seluruh sumber daya yang dimilki dalam sebuah proses transformasi yang terkendali, untuk memberikan nilai pada produk yang dihasilkan sesuai dengan kebijaksanaan perusahaan dan mendistribusikannya kepada konsumen yang dibidik.

2. Supply Chain Management berfungsi sebagai mediasi pasar, yaitu memastikan apa yang dipasok oleh rantai suplai mencerminkan aspirasi pelanggan atau konsumen akhir tersebut. Dalam hal ini fungsi pemasaran yang akan berperan. Melalui pelaksanaan Supply Chain Management, pemasaran dapat mengidentifikasi produk dengan karakteristik yang diminati konsumen. Selanjutnya fungsi ini harus mampu mengidentifikasi seluruh 
atribut produk yang diharapkan konsumen tersebut dan mengkomunikasikan kepada perancang produk. Apabila seleksi rancangan produk sudah dilakukan dan dilakukan pengujian maka produk dapat diproduksi. Sehingga Supply Chain Management akan berperan dalam memberikan manfaat seperti point 1 tersebut.

Ditinjau dari segi ongkos, masing-masing fungsi di atas berkaitan dengan ongkos, yaitu:

1. Fungsi pertama berkaitan dengan ongkos-ongkos fisik, yakni ongkos material, ongkos penyimpanan, ongkos produksi, ongkos transportasi, dan sebagainya.

2. Fungsi kedua berkaitan dengan biaya-biaya survey pasar, perancangan produk, serta biaya-biaya akibat terpenuhinya aspirasi konsumen oleh produk yang disediakan oleh rantai supply chain. Ongkos-ongkos ini bisa berupa ongkos markdown, yakni penurunan harga produk yang tidak laku dengan harga normal, atau ongkos kekurangan supply yang dinamakan dengan stockout cost.

\section{Prinsip-prinsip Supply Chain Management}

Prinsip terpenting yang harus diperhatikan dalam sinkronisasi aktivitasaktivitas sebuah supply chain adalah menciptakan hasil yang lebih besar, tidak hanya bagi tiap anggota rantai tetapi bagi keseluruhan sistem. Kesuksesan implementasi dari prinsip ini membutuhkan perubahan-perubahan pada tingkatan strategis maupun taktis. Sebaliknya kegagalan biasanya ditandai oleh ketidakmampuan manajemen mendefinisikan langkah-langkah yang harus ditempuh dalam menggiring komponen-komponen supply chain yang kompleks ke arah yang sama.

Anderson, Britt \& Frave (1997) memberikan 7 prinsip Supply Chain Management untuk membantu para manajer dalam merumuskan strategi pelaksanaan Supply Chain Management, yaitu:

1. Segmentasi pelanggan berdasarkan kebutuhannya.

2. Sesuaikan jaringan logistik untuk melayani kebutuhan pelanggan yang berbeda.

3. Dengarkan signal pasar dan jadikan signal tersebut sebagai dasar dalam perencanaan kebutuhan (demand planning) sehingga bisa menghasilkan ramalan yang konsisten dan alokasi sumber daya yang optimal.

4. Diferensiasi produk pada titik yang lebih dekat dengan konsumen dan percepat konversinya di sepanjang rantai supply.

5. Kelola sumber-sumber supply secara strategis untuk mengurangi ongkos kepemilikan dari material maupun jasa.

6. Kembangkan strategi teknologi untuk keseluruhan rantai supply yang mendukung pengambilan keputusan berhirarki serta berikan gambaran yang jelas dari aliran produk, jasa, maupun informasi.

7. Adopsi pengukuran kinerja untuk sebuah supply chain secara keseluruhan dengan maksud untuk meningkatkan pelayanan kepada konsumen akhir.

\section{E. Area Cakupan Supply Chain Management}

Apabila mengacu pada sebuah perusahaan manufaktur, kegiatan-kegiatan utama yang masuk dalam klasifikasi Supply Chain Management adalah : 
1. Kegiatan merancang produk baru (product development)

2. Kegiatan mendapatkan bahan baku (procurement)

3. Kegiatan merencanakan produksi dan persediaan ( planning and control)

4. Kegiatan melakukan produksi ( production)

5. Kegiatan melakukan pengiriman ( distribution )

\section{Pengembangan Produk}

Sangat penting terutama bagi industri inovatif seperti industri garmen, komputer, elektronik, packaging, dan sebagainya. Hal ini dikarenakan product life cycle-nya pendek. Sebuah rancangan produk bisa memakan waktu dan biaya yang sangat besar, padahal disisi lain perusahaan dituntut untuk bisa menghasilkan rancangan dalam waktu cepat dan biaya yang murah.

Dalam merancang perusahaan harus mempertimbangkan beberapa hal :

1. Aspirasi atau keinginan pelanggan, oleh karena itu dibutuhkan riset pasar yang memadai.

2. Produk yang dirancang harus mencerminkan ketersediaan dan sifat-sifat bahan baku. Dalam praktek SCM modern,

3. melibatkan supplier adalah kunci dalam proses perancangan produk baru Fasilitas produksi yang akan dimiliki atau dibangun, jadi aspek manufacturability perlu dipertimbangkan.

4. Produk yang dirancang harus sedemikian rupa sehinga kegiatan pengiriman mudah dilakukan dan tidak menimbulkan biaya-biaya persediaan yang berlebihan disepanjang suppply chain.

5. Aspek lingkungan, dituntut rancangan yang ramah lingkungan dan mudah didaur ulang.

\section{Pembelian (Procurement)}

Bagian pembelian dituntut mempunyai keahlian bernegosiasi, memiliki kemampuan untuk menerjemahkan strategis perusahaan ke dalam system pemilihan dan evaluasi supplier.

Tugas rutinnya adalah melakukan pembelian bahan baku, komponen, jasa dan sebagainya.

Bagian ini diharapkan dapat menciptakan kolaborasi jangka panjang dengan supplier-supplier relevan, melibatkan mereka dalam perancangan produk baru, mengevaluasi supply risk dan sebagainya.

\section{Perancangan dan Pengendalian}

Bagian ini bertugas untuk menciptakan koordinasi taktis maupun operasional sehingga kegiatan produksi, pengadaan material, maupun pengiriman produk bisa dilakukan dengan efisien dan tepat waktu.

Koordinasi yang dilakukan tidak hanya di internal tapi dalam supply chain, misal menentukan berapa banyak produk akan diproduksi, informasi tentang data penjualan terakhir di tingkat ritel serta berapa banyak stock produk yang masih mereka miliki adalah penting bagi pabrik.

Bahkan ritel dengan perusahaan saling koordinasi untuk menentukan rencana produksi jangka menengah atau pendek ( P\&G, Sara Lee, K-Mart, Warner Lambert) 


\section{Produksi}

Bagian ini bertugas secara fisik melakukan transformasi dari bahan baku, bahan setengan jadi atau komponen menjadi produk jadi. perusahaan.

Kegiatan produksi dalam konteks SCM tidak harus dilakukan dalam

Banyak perusahaan melakukan outsourcing yaitu memindahkan kegiatan produksi ke pihak subkontraktor, sementara perusahaan konsentrasi ke kegiatan yang menjadi core competency mereka. Contoh perusahaan sepatu Nike.

Dalam kegiatan produksi, konsep lean manufakturing yang mementingkan efisiensi dan agile manufacturing yang menekankan pada fleksibilitas dan ketangkasan merespon perubahan adalah dua hal yang penting.

\section{Distribusi/ pengiriman}

Tugas dalam lingkup supply chain adalah mengirim produk tersebut agar sampai di tangan pelanggan pada waktu dan tempat yang tepat.

Aktivitas ini dapat dilakukan sendiri oleh perusahaan atau diserahkan ke perusahaan jasa transportasi.

Dalam cakupan kegiatan distribusi, perusahaan harus merancang jaringan distribusi yang tepat dengan mempertimbangkan aspek biaya, aspek fleksibilitas dan aspek kecepatan respon terhadap pelanggan.

\section{F. Persyaratan Penerapan Supply Chain Management}

Sebagai suatu konsep yang melibatkan banyak pihak sebagai mata rantai, Supply Chain Management menuntut beberapa persyaratan yang tidak hanya terkait dengan material, tetapi juga informasi. Syarat utama dari penerapan Supply Chain Management tentunya dukungan manajemen. Manajemen semua level dari strategis sampai operasional harus memberikan dukungan mulai dari proses perencanaan, pengorganisasian, koordinasi, pelaksanaan, sampai pengendalian.

Selain dukungan manajemen, syarat lain merupakan syarat yang melibatkan faktor eksternal yaitu pemasok dan distributor. Sebelum membangun komitmen dan melaksanakan 'kontrak kerja' dengan para pemasok, maka perusahaan terlebih dahulu harus melaksanakan evaluasi pemasok. Sebagai catatan, melaksanakan evaluasi pemasok untuk pemasok yang 'bermain' dalam pasar yang monopoli tentunya sulit dan tidak bisa dilaksanakan, sehingga yang perlu dilakukan untuk kondisi ini adalah membangun kemitraan dalam suatu kesepakatan.

Evaluasi pemasok dilakukan apabila untuk material yang sama dapat diperoleh lebih dari satu alternatif pemasok. Setidaknya ada tiga kriteria dalam melakukan evaluasi pemasok, yaitu: keadaan umum pemasok, keadaan

pelayanan, dan keadaan material. Beberapa contoh indikator dari setiap kriteria evaluasi pemasok adalah sebagai berikut (Gaspersz, 2002):

1. Keadaan umum pemasok

a. Ukuran atau kapasitas produksi

b. Kondis finansial

c. Kondisi operasional

d. Fasilitas riset dan desain

e. Lokasi geografis

f. Hubungan dagang antar industri 
2. Keadaan pelayanan

a. Waktu penyerahan material

b. Kondisi kedatangan material

c. Kuantitas pemesanan yang ditolak

d. Penanganan keluhan dari pembeli

e. Bantuan teknik yang diberikan

f Informasi harga yang diberikan

3. Keadaan material

a. Kualitas material

b. Keseraaman material

c. Jaminan dari pemasok

d. Keadaan pengepakan (pembungkusan)

Dari ketiga kriteria tersebut, bobot (berdasarkan tingkat kepentingan) yang terbesar diberikan pada kriteria keadaan material, karena keadaan material akan mempengaruhi kinerja fungsi produksi dan operasi khususnya kualitas produk. Selanjutnya dilakukan penilaian untuk setiap indikator dan dihitung total skor-nya.

Syarat berikutnya adalah pemilihan distributor sebagai perantara produk perusahaan sampai ke tangan konsumen akhir. Intensitas saluran distribusi yang ideal bagi suatu perusahaan adalah bagaimana menyajikan jenis produk secara luas dalam pemuasan kebutuhan konsumen (Sitaniapessy, 2001). Penggunaan distributor yang terlalu sedikit dapat membatasi penyebaran jenis produk dalam aktivitas pemasaran. Sebaliknya, penggunaan distributor yang terlalu banyak dapat mengganggu brand image dalam posisinya berkompetisi. Satu kunci yang penting dalam mengelola saluran distribusi adalah menentukan berapa banyak saluran distribusi yang dikembangkan serta membentuk suatu pola kemitraan yang menunjang pemasaran suatu produk dalam area pemasaran tertentu.

\section{G. Peran Teknologi Internet}

Aplikasi internet dalam konteks Supply Chain Management yaitu :

1. Electronic Procurement ( e-Procurement)

2. Electronic Fulfillment ( e-Fulfilment)

\section{Electronic Procurement}

Salah satu model pengadaan yang mendukung hubungan jangka pendek adalah e-Auction yaitu suatu aplikasi untuk mendukung kegiatan lelang yang dilakukan secara elektronik. Pada model ini pembeli bisa mengundang beberapa calon supplier untuk menawarkan harga atas produk dengan spesifikasi dan jumlah tertentu dalam waktu yang telah ditentukan. Supplier dengan harga rendah yang akan dianggap menang. Proses lelang ini dilakukan dengan media Internet.

\section{Electronic Fulfilment}

Beberapa kegiatan yang termasuk dalam proses fulfilment adalah:

1. Menerima order dari pelanggan. Pelanggan bisa memesan produk melalui telepon, fax, e-mail, atau web based ordering.

2. Mengelola transaksi termasuk proses pembayaran.

3. Manajemen gudang meliputi pengendalian persediaan produk dan kegiatan administrasi gudang secara umum. 
4. Manajemen transportasi Keputusan mode dan rute transportasi termasuk di dalamnya.

5. Komunikasi dengan pelanggan untuk memberikan informasi status pesanan, dukungan teknis, dan sebagainya

6. Kegitan reverse logistics yang berupa pengembalian produk ke bagian supply chain akibat pengembalian dari pelanggan.

\section{Referensi}

Narendra Agrawal, Sthepen A. Smith, 2008, Retail Supply Chain Management, Quantitaives Model and Empirical Studies, Springer.

Yolanda M. Siagian, Cetakan II 2007, Aplikasi Supply Chain management dalam Dunia Bisnis, Grasindo

Barry Render, Jay Haeizer, 2001, Prinsip-Prinsip Manajemen Operasi, Salemba Empat.

Richardus Eko Indrajit dan Richardus Djokopranoto, 2002, Konsep Manajemen Supply Chain: Cara Baru Memandang Mata Rantai Penyediaan Barang,. Jakarta: Gramedia Widyasarana Indonesia.

Chopra, S., and Meindl, P. (2001). Supply chain management: Strategy, planning, and operations. New Jersey - Prentice-Hall.

Pujawan, I N. (2005). Supply chain management. Guna Widya.

Simchi-Levi, D., Kaminski, P., and Simchi-Levi, E. (2000). Designing and managing the supply chain: Concept, strategies, and case studies. Irwin McGraw-Hill.

Handfield, R., and Nichols, Jr., E. L. (2002). Supply chain redesign: Transforming supply chains into integrated value systems. New Jersey: Financial Times - Prentice Hall.

http://adnanedoudou.unblog.fr/tag/supply-chain-management-logistics-procurement purchasing/ 